\title{
Apologetika Tentang Kristologi
}

\author{
Jermia Djadi
}

Apologetika termasuk teologi sistematik yang intinya mengenai dogmatika dan etika. Mengingat ruang lingkup teologi sistematik sangat luas, maka pada kesempatan ini yang akan dibahas hanya beberapa hal penting, seperti pengertian apologetika, tugas apologetika, dan apologetika tentang Kristologi yang dianggap paling mendasar untuk diketahui agar kita mampu memberikan argumentasi terhadap pertanyaan-pertanyaan yang sering muncul tentang Kristologi.

\section{Pengetian Apologetika}

Perkataan apologia dan apologeomai (Yunani) sebaiknya diterjemahkan 'pembelaan" atau "pertanggungjawaban" dan "membela diri" atau "mempertanggungjawabkan diri". Ungkapan ini berulangulang dapat dijumpai dalam Perjanjian 'Baru. Dalam Kamus Kittel, seperti yang dikutip oleh J. Verkuyl disebutkan sebagai berikut.

Pertama, arti apologia dalam Kisah Para Rasul 25:16 ialah kesempatan yang diberikan kepada seorang pesakitan untuk membela dirinya terhadap dakwaan dalam suatu perkara.. Paulus berbicara di hadapan Agripa tentang kesempatan yang diberikan kepadanya sebagai warga Negara Roma "untuk membela diri (apologia) terhadap tuduh in itu." Dan dalam 2 Timotius 4:16 dikatakan bagaimana ia menggunakan kesempatan itu di Roma untuk pertama kalinya mengajukan pembelaan dalam perkara pendawaan atas dirinya.

Kedua, arti apologia ialah pidato pembelaan. Baik pidato yang diucapkan Paulus di Yerusalem maupun pidatonya di hadapan Festus dan Agripa serta pidato Stefanus di hadapan Dewan Agung itu disebut apologia dalam Kisah Para Rasul. ${ }^{1}$

Akhirnya, panggilan untuk apologia dikemukakan dalam Filipi 1:16 dan Filipi 1:7. Di sini arti perkataan itu sudah jauh lebih mendekati arti teologisnya. Dalam bagian ini Paulus memakai perkataan apologia itu dalam arti membela kebenaran Injil pada umumnya.

1J. Verkuyl, Fragmentika Apologetika (Jakarta: Badan Penerbit Kristen, 1966), 7-8. 


\section{Hubungan Apologi dan Apologetika}

Sehubungan dengan apa yang diartikan dalam Alkitab seperti telah diuraikan di atas, maka apologi dapat diartikan sebagai pertanggungjawaban atas isi iman Kristen terhadap mereka yang menuntut pertanggungjawaban dari kita. Apologetika dapat di- artikan sebagai pemikiran secara ilmiah tentang pertanyaan yang diajukan kepada kita dan cara bagaimana memberi peertanggungjawaban atas kepercayaan kita. Jadi antara apologi dan apologetika terdapat hubungan yang erat sekali. Kedua-duanya ialah mengenai pertanggungjawaban atas isi iman itu. Bedanya hanya dalam tekanan dan sasaran.

Suatu apologi diberikan dengan tulisan atau lisan kepada mereka yang mengajukan pertanyaan-pertanyaan. Jadi, apologi itu terutama diperuntukkan bagi mereka yang masih belum memeluk agama Kristen, atau yang masih meragukan kebenaran iman Kristen atau yang hendak memberantasnya. Sedangkan apologetika istimewa diperuntukkan bagi mereka yang dipanggil untuk memberikan apologi. Jadi, apologetika adalah suatu alat pembantu bagi mereka yang memberikan apologi itu. ${ }^{2}$

\section{Tugas Apologetika}

Adapun tugas apologetika adalah sebagai berikut.

Pertama, Apologetika harus membuka kedok-kedok prasangka. Ia harus menyingkirkan tirai ketidaktahuan tentang Injil itu. Ia harus melumpuhkan argumentasi-argumentasi yang orang kemukakan untuk menyangkal kebenaran Injil itu. Ia harus memaparkan bahwa perlawanan terhadap Injil itu berpangkal pada apriori-apriori dan pendapat-pendapat tertentu yang tak dapat dipertahankan.

Kedua, apologetika bertugas untuk membantu orang-orang supaya bertemu muka dengan muka dengan Yesus Kristus. Banyak orang yang belum pernah beroleh kesempatan untuk mendengar Injil itu dengan baik, akibat ketidaktahuan, prasangka-prasangka, dan sebagainya. Apologetika justru hendak membantu mereka supaya beroleh kesempatan itu di mana mereka sendiri dapat mendengar suara Tuhan Yesus.

Ketiga, Apologetika tak mungkin memaksakan orang-orang untuk mengambil keputusan. Pemilihan itu tak dapat diambilalih oleh apologetika. Yang dilakukan oleh apologetika ialah untuk membawa orang-orang sampai ke ambang pintu di mana orang-orang itu sendiri yang harus mengambil keputusan: mau menurut Kristus atau tidak. ${ }^{3}$

${ }^{2}$ Tbid., 11 .

${ }^{3}$ Ibid., 26-27. 


\section{Bagaimana Apologi dan Apologetika Itu Dilaksanakan?}

Pertama, harus dengan rendah hati. Injil dan iman itu telah kita diterima sebagai suatu kasih karunia. Injil itu bukan hasil pemikiran kita. Oleh sebab itu, setiap apologi harus diberikan dalam segala kerendahan kati (II Korintus 11:7).

Kedua, Harus dengan lemah lembut dan sabar (I Petrus 3:15-16).

Ketiga, Dengan cara meminta dengan sangat dan jangan secara memaksa, seperti Paulus meminta kepada orang Korintus, "Berilah dirimu didamaikan dengan Allah" (II Korintus 5:20) dan seperti undangan Yesus dalam Wahyu 3:20, "Lihatlah, Aku berdiri di muka pintu sambil mengetok; jika ada orang membuka pintu, Aku akan masuk mendapatkannya ...."

Keempat, Dengan berani, dalam ketakutan kepada Allah dan bukan dalam ketakutan kepada manusia.

Kelima, Dengan meminta pertimbangan orang-orang disertai seruan untuk bertobat dengan seluruh keberadaannya. ${ }^{4}$

\section{Apologetika Tentang Kristologi}

Penyangkalan Kellahian Kristus dar Apologia

\section{Penyangkalan Keilahian Kristus}

Dalam literatur Kristen abad mula-mula, Kristus disebutkan sebagai Allah dan manusia, Anak Manusia juga Anak Allah. KeberadaanNya yang tanpa dosa terus dipegang teguh dan la adalah tujuan penyembahan yang paling benar. Pada saat yang sama, masalah yang timbul tentang Kristus mengenai konsep bahwa Ia adalah Allah dan manusia serta kesulitan-kesulitan yang tercakup di dalamnya, belum sepenuhnya dirasakan oleh orang Kristen abad mula-mula. Mereka hanya melihatnya sebagai suatu hal yang bertentangan. Hal ini mungkin disebabkan oleh paham Yudaisme dengan tekanan monoteismenya yang memberikan banyak pengaruin pada orang Kristen mula-mula yang berlatar belakang Yahudi.

Berikut ini akan dikemukakan kelompok/tokoh yang menyangkal keilahian Kristus.

Pertama, Kaum Ebonit menyangkal keilahian Kristus. Mereka beranggapan bahwa Yesus dikandung secara insani, sehingga Ia tetap sebagai manusia biasa, anak Yusuf dan Maria. Mereka mengakui bahwa Yesus setelah dibaptis mempunyai kuasa Ilahi di dalam diri-Nya karena

${ }^{4}$ Ibid., 27. 


\section{Apologetika Tentang Kristologi}

Roh Kudus memenuhi Dia secara berkelimpahan. "Setelah Yesus dibaptis, Roh Allah turun ke atas-Nya seperti burung merpati', tetapi meninggalkan Dia sebelum penyaliban.

Kedua, Kaum Alogi menolak tulisan-tulisan Yohanes sebab mereka menganggap doktrin Yohanes tentang Logos bertentangan dengan seluruh Perjanjian Baru. Mereka beranggapan bahwa Yesus hanyalah manusia biasa, walaupun secara ajaib dilahirkan oleh seorang perawan dan mereka mengajarkan bahwa Kristus turun ke atas Yesus pada saat dibaptis yang menyebabkan Dia memiliki kekuatan supranatural.

Ketiga, Paulus dari Samosata adalah tokoh utama ajaran yang membedakan antara Yesus dan Logos. Ia menganggap bahwa Yesus adalah manusia, sama seperti manusia lain yang dilahirkan oleh Maria; sedangkan Logos dianggap sebagai pemikiran Ilahi yang tidak berpribadi, yang kemudian tinggal dalam Kristus sejak waktu Ia dibaptis dan dengan demikian memberikan' kuasa bagi tugas-tugas-Nya yang besar. ${ }^{5}$

\section{Apologia}

Dari sudut pandang penyangkalan ini, maka tugas para tokoh apologetika adalah mempertahankan doktrin keilahian Kristus. Berkenaan dengan penyangkalan keilahian Kristus yang sudah begitu menyebar, sangatlah penting bagi kita untuk berpegang pada bukti-bukti Alkitab tentang keilahian Kristus. Bukti-bukti itu sedemikan banyaknya, sehingga tak seorang pun yang mengakui bahwa Alkitab sebagai firman Allah yang tidak bersalah, dapat meragukan keilahian Kristus.. Buktibukti Alkitab tentang keilahian Kristus dapat dilihat dalam pembahasan tentang Allah Tritunggal bahwa Anak dikenal sebagai Allah. Perjanjian Baru menunjukkan bahwa Kristus adalah Allah dengan berbagai cara.

Pertama, Anak memiliki sifat-sifat Ilahi. Kristus memiliki lima sifat yang secara khas dan jelas adalah Ilahi: kekal, mahahadir, mahatahu, mahakuasa, dan tidak berubah. (1) Yesus itu kekal. Ia sudah ada bukan saja sebelum Yohanes Pembaptis (Yohanes 1:15), sebelum Abraham (Yohanes 8:58), dan bahkan sebelum dunia dijadikan (Yohanes 17:5, 24), melainkan Dialah "... yang sulung, lebih utama daripada yang diciptakan ...." (Kolose 1:5), yang sudah ada "pada mulanya" (Yohanes 1:1). (2) Yesus itu Mahahadir. Ia berada di sorga sekalipun sedang berada di bumi (Yohanes 3:13) dan berada di bumi ketika Ia di sorga (Matius $18: 20 ; 28: 20$ ). Ia memenuhi segala sesuatu (Epesus 1:23). (3) Yesus Mahatahu. Yesus tahu segala sesuatu (Yohanes 16:30; 21:17).

${ }^{5}$ Louis Berkhof, Teologi Sistematika: Doktrin Kristus (Surabaya: Lembaga Reformed Injili Indonesia, 1996), 9. 
Sesungguhnya di dalam Dia tersembunyi segala harta hikmat dan pengetahuan" (Kolose 2:3). Ia mengetahui apa yang ada di dalam hati manusia (Yohanes 2:24-25), Ia mengetahui riwayat hidup perempuan Samaria (Yohanes 4:29), Ia mengetahui pikiran manusia (Lukas 6:8; 11:17), Ia mengetahui waktu dan cara-Nya meninggalkan dunia ini (Matius $16: 21$; Yohanes $12: 33 ; 13: 1$ ), la juga mengetahui siapa yang akan mengkhianati-Nya (Yohanes 6:70-71), serta Ia mengetahui keadaan akhir zaman ini (Matius 24, 25). Ia mengenal Bapa dengan sangat akrab dan tak seorang pun yang dapat mengenal Bapa seperti itu (Matius 11:27). (4) Yesus itu Mahakuasa (Yohanes 5:19). Dialah Allah Yang Perkasa (Yesaya 9:5; Wahyu 1:8), Ia menopang segala yang ada dengan firmanNya yang penuh kekuasaan" (Ibrani 1:3), dan juga segala kuasa telah diserahkan kepada-Nya (Matius 28:18). Ia berkuasa atas setan-setan/ roh-roh jahat (Markus 5:11-15), Ia berkuasa atas penyakit (Lukas 4:3841), Ia berkuasa atas kematian (Matius 9:18-25; Lukas 7:12-16; Yohanes 11:38-44), ia berkuasa atas unsur-unsur alamiah (Matius 21:19; Yohanes 2:3-11), ya, Ia berkuasa atas segala sesuatu (Matius 28:18). (5) Yesus tidak berubah. Ibrani $1: 12 ; 13: 8)$. Hal ini berlaku bagi semua rencana, janji, serta diri-Nya sendiri.

Kedua, Anak memiliki jabatan-jabatan Ilahi. Yesus adalah Pencipta (Yohanes 1:3; Kolose 1:16; Ibrani 1:10) serta Penopang segala sesuatu yang ada (Kolose 1:17; Ibrani 1:3). Tidak ada hal yang kebetulan ataupun hukum alam yang menciptakan alam semesta atau menopang alam semesta. Pekerjaan tersebut adalah pekerjaan Ilahi (II Petrus 3:5-7).

Ketiga, Anak memiliki hak-hak istimewa Allah. Kristus mengampuni dosa (Matius 9:2; Lukas 7:47-48). Ia akan membangkitkan orang mati pada hari Kebangkitan (Yohanes 5:25-29; 6:39-40, 54; 11:25). Pada masa yang akan datang, semua orang kudus-Nya akan dibangkitkan; mereka akan dibangkitkan dari tubuh yang busuk dan dari kematian; mereka akan bangkit dan takkan mati lagi; dan mereka akan dibangkitkan oleh kuasa yang ada di dalam Kristus dan bukan oleh kuasa Roh Kudus. Akhirnya, Ia akan menghakimi (Yohanes 5:22) orang-orang percaya (Roma 14:10; Il Korintus 5:10), binatang itu beserta para pengikutnya (Wahyu 19:15, 19-20) dan bangsa-bangsa (Matius 25:3132; Kisah 10:42; II Timotius 4:1; I Petrus 4:5).

Keempat, Anak disamakan dengan Yehova dari Perjanjian Lama. Apa yang dikatakan dalam Perjanjian Lama mengenai Yehova juga dikatakan mengenai Kristus dalam Perjanjian Baru. Ia adalah Pencipta (Mazmur 102:26-28; Ibrani 1:10-12), Ia harus dipandang sebagai Yang Kudus (Yesaya 8:13; I Petrus 3:15), dan Ia menjadi sasaran iman (Yoel 2:32; Roma 10:9, 13). 
Kelima, Anak memiliki atribut-atribut, gelar, atau nama yang menyatakan keilahian-Nya. (1) Yesus memakai beberał u kiasan yang menyiratkan sifat adikodrati, misalnya, Yesus mengatakan, "Akulah roti yang turun dari sorga" (Yohanes 6:41, 50); "Akulah pintu; barangsiapa masuk melalui Aku, ia akan selamat" (Yohanes 10:9); "Akulah jalan dan kebenaran dan hidup, tidak ada seorang pun yang datang kepada Bapa, kalau tidak melalui Aku" (Yohanes 14:6); "Akulah pokok anggur dan kamulah ranting-rantingnya. Barangsiapa tinggal di dalam Aku dan Aku di dalam dia, ia berbuah banyak, sebab di luar Aku kamu tidak dapat berbuat apa-apa" (Yohanes 15:5). (2) Kristus juga memakai beberapa gelar bagi diri-Nya yang menyiratkan keilahian-Nya, dengan ungkapanungkapan, seperti "Alfa dan Omega", "Yang Pertama dan Yang Terkemudian", "Yang Awal dan Yang Akhir" (Wahyu 22:13), "kebangkitan dan hidup" (Yohanes 11:25), dan "Amin, Saksi yang setia dan benar, permulaan dari ciptaan Allah" (Wahyu 3:14). Lagi pula Yesus mengatakan, "Sebelum Abraham jadi, Aku telah ADA" (Yohanes 8:58; bdg. 3:14). (3) Yesus memakai beberapa nama atau gelar yang menyatakan keilahian-Nya, misalnya, (a) Ia disebut Imanuel. Matius secara jelas mengenakan Yesaya 7:14 kepada Yesus (Matius 1:22-23). Ia lahir dari seorang perawan dan diberi nama Imanuel, yang artinya Allah menyertai kita. Dalam Perjanjian Baru nama ini hanya muncul sekali dalam Matius, walaupun konsep Allah menyertai kita itu ada juga dalam kitab lain (Yohanes 1:14; Wahyu 21:3). (b) Istilah "Firman" (Logos) dipakai untuk menekankan keilahian-Nya (Yohanes 1:1-14; Wahyu 19:13). 44; 26:64). (c) Kristus disebut Tuhan. Dalam Perjanjian Baru, istilah Yunani untuk Tuhan dipakai dengan empat cara, yaitu untuk menunjuk kepada Allah Bapa (Matius 4:7; 11:25; Lukas 2:29;Kisah 17:24; Roma 4:8; II Korintus 6:17-18; Wahyu 4:8), untuk menunjukkan rasa hormat (Matius 13:27; 21:29; 27:63; Lukas 13:18; Yohanes 12:21), sebagai nama untuk seorang majikan atau pemilik (Matius 20:8; Lukas 12:46; Yohanes 15:15; Kolose 4:1), dan sebagai sebutan bagi Kristus (Matius 7:22; 8:2; 14:28; Markus 7:28). Gelar "Tuhan" yang sering dipakai untuk Yesus merupakan terjemahan dari nama Ibrani Yehova. Jadi, Kristus disamakan dengan Yehova dari Perjanjian Lama (Yohanes 12:40:41; Roma 10:9, 13; dan I Petrus 3:15). (d) Kristus dinamakan Anak Allah. Gelar ini dipakai oleh Yesus untuk diri-Nya dalam Injil Yohanes (Yohanes 5:18; 10:33, 36). Pernyataan bahwa Yesus Anak Allah jelas dimaksudkan untuk menunjuk kepada keilahian-Nya. Hal ini tersirat dalam istilah "AnakNya Yang Tunggal" (Yohanes 3:16, 18). Ketika Yesus mengakui diriNya sebagai Anak Allah, Ia dituduh telah menghujat Allah (Matius 26:6365 , banding Yohanes $5: 18 ; 10: 36)$. Sebagai Anak Allah, Ia akan 
melaksanakan penghakiman (Yohanes 5:22), memiliki hidup dalam diriNya dan menghidupkan siapa saja yang dikehendaki-Nya (Yohanes 5:21, 26) serta memberikan hidup kekal (Yohanes 10:10). Yesus juga disebut sebagai Anak Allah dalam arti Mesias yang diurapi oleh Tuhan (Yohanes $1: 49 ; 11: 27$ ). (e) Yesus disebut Allah sebanyak beberapa kali dalam Perjanjian Baru. Dalam Yohanes 1:1 penekanannya sangat kuat dalam bahasa Yunani. Ayat ini berbunyi, "Dan Firman itu adalah Allah." Ia bukan saja Anak Yang Tunggal, tetapi juga Allah (Yohanes 1:18). Thomas menyebut Kristus, "Tuhanku dan Allahku" (Yohanes 20:28). I Yohanes 5:20 berbunyi, "dan kita ada di dalam yang benar di dalam Anak-Nya Yesus Kristus. Ia adalah Allah yang benar dan hidup yang kekal."

\section{Penyangkalan Kemanusiaan Kristus dan Apologia}

\section{Penyangkapan Kemanusiaan Kristus}

Pada abad mula-mula, pernah ada ajaran-ajaran sesat yang menyangkal realita kemanusiaan Kristus, misalnya:

Pertama, Ajaran Gnostisisme mengatakan bahwa Yesus Kristus tidak pernah memiliki tubuh manusia yang sebenarnya, sehingga Ia tidak benar menderita. Ia hanya tampak seperti memiliki sifat manusia sejati. Selanjutnya penganut Gnostisisme mengajarkan bahwa zat yang nyata itu jahat, karena itu, tidak mungkin terjadi penjelmaan yang sesungguhnya dari Allah menjadi manusia. ${ }^{6}$

Kedua, Kaum Doketisme mengajarkan bahwa Firman Allah hanya secara semu saja menjadi manusia.? Mereka mengatakan bahwa Yesus hanya kelihatannya saja mempunyai tubuh. Mereka bersikeras bahwa Yesus murni makhluk rohani yang tidak mempunyai apa-apa, kecuali dalam penampakannya saja mempunyai tubuh. Mereka menolak sepenuhnya kenyataan bahwa Yesus pernah mempunyai tubuh fisik. ${ }^{8}$ Pada zaman para rasul, ajaran Doketisme ini sangat ditentang (I Yohanes $4: 2)$.

\section{Apologia}

Pada saat ini, kemanusiaan Kristus jarang dipersoalkan. Sebagian besar dari gereja mula-mula menerima ajaran bahwa Kristus adalah manusia dan Allah. Penyimpangan dari doktrin Alkitab lebih banyak terjadi karena menolak sifat keilahian Kristus dan bukan menolak sifat kemanusiaan-Nya. Kristus harus menjadi manusia sungguh jika Ia hendak menebus manusia dari dosa. Apa saja yang menjadi bukti bahwa Yesus adalah manusia yang sungguh?

${ }^{6}$ M.E. Manton, Kamus Istilah Teologi: Inggris-Indonesia (Malang: Yayasan Gandum Mas, 1995), 72-73.

${ }^{7} \mathrm{R}$. Soedarmo, Kamus Istilah Theologia (Jakarta: BPK Gunung Mulia, 1986), 25.

${ }^{8}$ William Barclay, Pemahaman Alkitab Setiap Hari, Surat-Surat Yohanes dan Surat Yudas (Jakarta: BPK Gunung Mulia, 1993), 8-9. 


\section{Apologetika Tentang Kristologi}

Pertama, Yesus lahir seperti manusia lainnya. Yesus lahir dari seorang perempuan (Galatia 4:4). Kenyataan ini dikuatkan oleh kisahkisah kelahiran-Nya dari seorang anak dara (Matius 1:18-2:11; Lukas 1:30-38; 2:1-20). Oleh karena itu, Yesus disebut "Anak Daud, Anak Abraham" (Matius 1:1) dan dikatakan bahwa Ia "menurut daging diperanakkan dari keturunan Daud" (Roma 1:3). Dalam kaitan ini telah diajukan satu pertanyaan penting, "Bilakah Kristus itu lahir dari seorang perawan?" "Apakah Ia mewarisi sifat berdosa dari ibu-Nya?" Alkitab dengan jelas menunjukkan bahwa Yesus tidak berhubungan dengan dosa. Alkitab menandaskan bahwa Yesus "tidak mengenal dosa" (II Korintus 5:21); dan bahwa Ia adalah "yang saleh, tanpa salah, tanpa noda, yang terpisah dari orang-orang berdosa" (Ibrani 7:26); dan bahwa " di dalam Dia tidak ada dosa" (I Yohanes 3:5). Pada saat diberitahukan bahwa Maria akan melahirkan Anak Allah, Gabriel menyebutkan bahwa Yesus sebagai "kudus" (Lukas 1:35). Iblis tak berkuasa apa-apa atas diri Yesus (Yohanes 14:30); ia tak ada hak apa pun atas Anak Allah yang tidak berdosa itu. "Dosalah yang membuat iblis berkuasa atas manusia, tetapi di dalam Yesus tidak ada dosa. Melalui naungan ajaib Roh Kudus, Yesus lahir sebagai manusia yang tak berdosa.

Kedua, Yesus tumbuh dan berkembang seperti manusia normal. Yesus berkembang secara normal sebagai halnya manusia. Oleh karena itu, dalam Alkitab dikatakan bahwa Ia "bertambah besar dan menjadi kuat, penuh hikmat, dan kasih karunia Allah ada pada-Nya" (Lukas $2: 40$ ), dan bahwa Ia "makin bertambah besar dan bertambah hikmatNya dan makin dikasihi oleh Allah dan manusia" (Lukas 2:52). Perkembangan fisik dan mental Kristus ini tidak disebabkan oleh karena sifat Ilahi yang dimiliki-Nya, tetapi diakibatkan oleh hukum-hukum pertumbuhan manusia yang normal. Perkembangan mental Yesus bukanlah semata-mata hasil pelajaran di sekolah pada zaman itu (Yoahanes 7:15), tetapi harus dianggap sebagai hasil pendidikan-Nya dalam keluarga yang saleh, kebiasaan-Nya untuk selalu hadir dalam rumah ibadah (Lukas 4:16), kunjungan-Nya ke Bait Allah (Lukas 2:4), penelaahan Alkitab yang dilakukan-Nya (Lukas 4:17), dan juga karena Dia menggunakan ayat-ayat Alkitab ketika menghadapi pencobaan dan karena persekutuan-Nya dengan Allah Bapa (Markus 1:35; Yohanes 4:3234).

Ketiga, Yesus memiliki unsur-unsur hakiki sifat manusia. Bahwa Kristus memiliki tubuh jasmani jelas dari ayat-ayat yang berbunyi, "Sebab dengan mencurahkan minyak itu ke tubuh-Ku, ...."(Matius 26:12); "Tetapi yang dimaksudkan-Nya dengan Bait Allah ialah tubuhNya sendiri" (Yohanes 21); "...tetapi Engkau telah menyediakan tubuh 
bagiku" (Ibrani 10:5); “... kita telah dikuduskan satu kali untuk selamalamanya oleh persembahan tubuh Yesus Kristus" (Ibrani 10:10). Bahkan setelah dibangkitkan Ia berkata, "Rabalah Aku dan lihatlah, karena hantu tidak ada daging dan tulangnya, seperti yang kamu lihat ada pada-Ku" (Lukas 24:39). Yesus bukan saja memiliki tubuh manusiawi yang fisik, Ia juga memiliki unsur-unsur sifat manusiawi lainnya, seperti kecerdasan dan sifat sukarela. Ia berpikir dengan logis. Alkitab berbicara tentang Dia sebagai memiliki jiwa atau roh (Matius 26:38; bdg. Markus 8:12; Yohanes 12:27; 13:21; Markus 2:8; Lukas 23:46). Ketika kita mengatakan bahwa Ia mengambil sifat seperti kita, harus selalu dibedakan antara sifat manusiawi dan sifat yang berdosa; Yesus memiliki sifat manusiawi, tetapi Ia tidak memiliki sifat yang berdosa.

Keempat, Yesus mempunyai nama manusia. Ia memiliki banyak nama manusia. Nama Yesus (Matius 1:21) adalah bentuk bahasa Yunani dari kata Ibrani Yehoshua, Yoshua (Yosua 1:1; Zakharia 3:1) atau Yeshua (Ezra 2:2) yang artinya Juruselamat. (2) Ia disebut anak Abraham (Matius 1:1) dan anak Daud. Nama anak Daud sering kali muncul dalam Injil Matius $(1: 1 ; 9: 27 ; 12: 23 ; 15: 22 ; 20: 30,31 ; 21: 9,15)$. Nama Anak Manusia terdapat lebih dari 80 kali dalam Perjanjian Baru. Nama Anak Manusia dipakai ketika menubuatkan tentang Kristus dalam Daniel 7:13 bdg. Matius 16:28. Nama ini dianggap oleh orang Yahudi sebagai mengacu kepada Mesias. Orang-orang Yahudi memahami bahwa istilah ini menunjuk kepada Mesias (Yohanes 12:34). Menyebutkan Kristus itu Anak Manusia adalah sama dengan menyebut Dia Anak Allah (Lukas 22:69, 70). Ungkapan itu bukan saja menunjukkan bahwa Ia benar-benar manusia, tetapi bahwa Ia juga adalah wakil seluruh umat manusia (bdg. Ibrani 2:6-9).

Kelima, Ia memiliki berbagai kelemahan yang tidak berdosa dari sifat manusia. Oleh karena itu, Yesus pernah lelah (Yohanes 4:6), lapar (Matius 4:2; 21:18), haus (Yohanes 19:28); Ia pernah tidur (Matius 8:24); Ia dicobai (Ibrani 2:18; 4:15; bdg. Yakobus 1:13); Ia mengharapkan kekuatan dari Bapa-Nya yang di sorga (Markus 12:28), mempersembahkan diri-Nya kepada Allah oleh Roh Kudus (Kisah 10:38; Ibrani 9:14). Orang-orang Kristen memiliki seorang imam besar di sorga dengan kemampuan yang tiada taranya untuk merasa belas kasihan terhadap mereka dalam semua bahaya, dukacita, dan pencobaan yang mereka alami dalam kehidupan, karena Ia sendiri mengalami semuanya itu dan karena Ia menjadi sama dengan manusia. Kembali harus ditekankan bahwa menyebutkan kelemahan-kelemahan dalam sifat Kristus tidaklah berarti kelemahan-kelemahan yang berdosa, melainkan kelemahan-kelemahan yang tidak berdosa dari sifat manusia. 
Keenam, Berkali-kali Yesus disebut sebagai manusia. Yesus menganggap diri-Nya sendiri manusia (Yohanes $8: 40$ ). Yohanes, Petrus, dan Paulus menyebut-Nya manusia (Yohanes 1:30; Kisah 13:38; I Korintus 15:21,47; Filipi 2:8). Kristus benar-benar diakui sebagai manusia (Yohanes $7: 27 ; 9: 29 ; 10: 33$ ), sehingga la dikenal sebagai orang Yahudi (Yohanes 4:9); bahkan setelah bangkit, Kristus tampak sebagai manusia (Yohanes $20: 15 ; 21: 4,5)$. Lagi pula, sekarang ini Ia berada di sorga sebagai manusia (I Timotius 2:5), Ia akan datang kembali (Matius 16:27, 28; 25:31; 26:64, 65), Ia akan datang kembali dengan adil sebagai manusia (Kisah 17:31).

\section{Perlunya Kedua Sifat itu Dalam Diri Kristus}

Di atas telah dikemukakan bukti-bukti Alkitab tentang kemanusiaan dan keilahian Kristus. Pada zaman sekarang, banyak orang tidak menyadari perlunya kedua sifat itu dalam diri Kristus. Bagi mereka Yesus hanyalah manusia, akan tetapi pada saat yang sama, mereka merasa terhalang untuk mengakui bahwa la adalah Allah. Perlunya kedua sifat itu sangat ditekankan sehubungan dengan doktrin Alkitab tentang "pendamaian."

Pertama, Perlunya kemanusiaan Kristus. Karena manusia berdosa, maka hukuman dosa haruslah ditanggung oleh manusia juga. Pembayaran upah dosa mencakup penderitaan tubuh dan jiwa yang hanya mungkin ditanggung oleh manusia (Yohanes 12:27: Kisah 3:18; Ibrani $2: 14 ; 9: 22$ ). Sangatlah perlu bahwa Yesus memiliki sifat manusia, bukan saja dengan semua sifat esensial-Nya, tetapi juga bersama semua kelemahan manusiawi yang mungkin dialami karena kejatuhan manusia dan dengan demikian harus turun ke dalam kerendahan yang paling rendah di mana manusia sudah jatuh (Ibrani 2:17,18). Pada saat yang sama, Ia harus menjadi seorang manusia yang tanpa dosa, sebab seorang manusia yang berdosa dan telah kehilangan nyawanya tentunya tidak dapat menjadi pendamai bagi orang lain (Ibrani 7:26).

Kedua, Perlunya keilahian Kristus. Dalam rencana keselamatan Allah sangatlah penting bahwa Pengantara itu harus juga Allah yang sejati. Hal ini periting dengan tujuan: (1) Ia dapat membawa korban yang nilainya tanpa batas dan memberikan ketaatan yang sempurna kepada hukum Allah; (2) Ia dapat menanggung murka Allah dan membawa penebusan, sehingga Ia dapat membebaskan orang lain dari kutukan hukum; dan (3) Ia dapat menerapkan buah-buah karya-Nya yang telah diselesaikan-Nya bagi mereka yang menerima Dia dengan iman. Manusia dengan hidupnya yang telah rusak, tidak dapat membayar upah dosa atau melakukan ketaatan yang sempurna kepada Allah. Manusia 
hanya dapat menanggung murka Allah dan kalau anugerah Allah yang menebusnya tidak ada, maka yang dapat dilakukan manusia hanyalah menanggung kutukan murka itu untuk selama-lamanya. ${ }^{9}$ Itulah sebabnya kedua sifat itu, yaitu kemanusiaan dan keilahian dalam diri Kristus sangat diperlukan.

\section{Penyangkalan Kebangkitan Kristus dan Apologia}

\section{Penyangkalan Kebangkitan Kristus}

Sejak abad mula-mula hingga abad ini, penyangkalan kebangkitan Kristus dilakukan dengan berbagai cara. Berita kebangkitan itu disangkal, ditolak, ditiadakan, dan dibantah. Berikut ini akan dikemukakan beberapa teori atau kelompok orang yang menyangkal kebangkitan Kristus, yaitu:

Pertama, Teori pencurian mayat. (1) Teori pencurian mayat sebagaimana dikemukan oleh pemimpin-pemimpin bangsa Yahudi dan pengikut-pengikutnya dapat kita baca dalam Injil Matius 28:1-15 sebagai berikut.

Setelah hari Sabat lewat, menjelang menyingsing fajar pada hari pertama minggu itu, pergilah Maria Magdalena dan Maria yang lain menengok kubur itu. Maka terjadilah gempa bumi yang hebat sebab seorang malaikat Tuhan turun dari langit dan datang ke batu itu dan menggulingkannya lalu duduk di atasnya.... Dan penjaga-penjaga itu gentar ketakutan dan menjadi seperti orang-orang mati. Akan tetapi malaikat itu berkata kepada perempuan-perempuan itu, "Janganlah kamu takut; sebab aku tahu kamu mencari Yesus yang disalibkan itu. Ia tidak ada di sini, sebab la telah bangkit, ....Mari, lihatlah tempat Ia berbaring. Dan segeralah pergi dan katakanlah kepada murid-muridNya bahwa Ia telah bangkit dari orang mati..."Mereka segera pergi dari kubur itu dengan takut dan dengan sukacita yang besar dan berlari cepat-cepat untuk memberitahukannya kepada murid-murid Yesus.... Ketika mereka di tengah jalan, datanglah beberapa orang dari penjaga itu ke kota dan memberitahukan segala yang terjadi itu kepada imamimam kepala. Dan sesudah berunding dengan tua-tua, mereka mengambil keputusan lalu memberikan sejumlah besar uang kepada serdadu-serdadu itu dan berkata, "Kamu harus mengatakan bahwa murid-murid-Nya datang malam-malam dan mencuri-Nya ketika kamu sedang tidur. Dan apabila hal ini kedengaran oleh wali negeri, kami akan berbicara dengan dia, sehingga kamu tidak beroleh kesulitan apa-

${ }^{9}$ Louis Berkhof, Teologi Sistematika: Doktrin Kristus (Surabaya: Lembaga Reformed Injili Indonesia, 1996), 38-39. 
apa." Mereka menerima uang itu dan berbuat seperti yang dipesankan kepada mereka. Dan cerita ini tersiar di antara orang Yahudi sampai sekarang ini. (2) Pada permulaan abad ke-20, di Eropa diterbitkan berbagai buku yang menyiarkan teori pencurian mayat ini. Seorang teolog yang terkenal menulis bahwa ada kemungkinan mayat Tuhan Yesus itu tertimbun oleh tanah pada waktu terjadi gempa bumi itu lalu hilang dengan begitu saja... Tetapi kini teori ini tidak begitu mempunyai arti lagi. Tokoh-tokoh pemimpin dalam dunia Yahudi modern menganggap teori ini kini sebagai suatu teori dusta yang teramat bodoh dan mereka lebih suka mendiamkannya. ${ }^{10}$

Kedua, Ada kelompok orang yang beranggapan bahwa sebenarnya bukan Tuhan Yesus yang tergantung pada kayu salib itu, melainkan suatu "bayangan semu" dari Dia atau seorang pengganti, seorang lain. "Mereka tidak menyalibkan Dia, melainkan orang yang serupa dengan Dia." Dalam kelompok lain, orang menyiarkan cerita bahwa Tuhan Yesus benar tergantung pada kayu salib itu, tetapi Ia tidak mati, melainkan hanya pinsan saja dan dalam keadaan demikian, kemudian Ia diambil dari kayu salib dan dibawa ke kuburan. Di kuburan itu, Ia terbangun dan kemudian pergi ke Kashmir, di mana Ia akhirnya meninggal dunia. ${ }^{11}$

\section{Apologia}

Gereja Kristen berdiri di dunia ini dengan kesaksian bahwa Tuhan Yesus yang disalibkan itu telah bangkit dari antara orang mati dan bahwa Ia tidak akan mati lagi, melainkan hidup sampai selama-lamanya. Yang tersalib itulah yang telah bangkit. Yang direndahkan itulah yang telah ditinggikan. Hamba Tuhan yang telah menanggung dosa itulah Tuhan itu. Kepada Dia yang telah menanggung penghakiman atas dosa-dosa kita itu, kepada-Nya telah diberikan nama di atas segala nama. Itulah inti kesaksian gereja Kristen. Itulah inti sari kesaksian teologi Kristen, teologi salib sekaligus teologi kebangkitan. Mati dan hidup gereja Kristen tergantung dari berita kebangkitan Kristus. Seandainya Kristus tidak dibangkitkan dari antara orang mati, maka Injil Matius, Markus, Lukas, dan Yohanes takkan ditulis. Seandainya Yesus Kristus tidak bangkit dari antara mati, maka takkan ada gereja Kristen. Seandainya Kristus tidak bangkit dari antara orang mati, maka saksi-saksi Kristen akan merupakan saksi-saksi palsu serta iman Kristen itu, iman tanpa dasar, tanpa harapan, dan kosong, seperti yang diungkapkan oleh Rasul Paulus dalam surat I

${ }^{10} \mathrm{~J}$. Verkuyl, Fragmenta Apologetika (Jakarta: Badan Penerbit Kristen, 1966), 150.

${ }^{11}$ Ibid., 152. 
kebangkitan Kristus yang terjadi pada hari Minggu, maka mereka mengubah hari ibadah mereka. Ibadah hari Minggu merupakan akibat kebangkitan Kristus. (4) Gereja Kristen merupakan akibat lainnya dari peristiwa kebangkitan Kristus.Tidak ada satu alasan apa pun yang dapat mendorong para murid-Nya untuk berkumpul bersama-sama untuk beribadah kepada Tuhan, kecuali mereka betul-betul yakin bahwa Kristus telah bangkit dari antara orang mati. Perkumpulan-perkumpulan mereka itu merupakan awal berdirinya gereja Kristen. Jadi, adanya gereja Kristen merupakan bukti tersendiri akan kebangkitan Kristus. (5) Akhirnya, kitab Perjanjian Baru itu sendiri merupakan akibat kebangkitan Kristus. Tak mungkin kitab ini ditulis kalau tidak terjadi kebangkitan. Evans mengatakan, "Bila Yesus tetap berada dalam kubur, kisah kehidupan dan kematian-Nya pastilah akan tetap terkubur bersama dengan Dia." Perjanjian Baru jelas merupakan akibat kebangkitan Kristus. ${ }^{12}$

\section{KEPUSTAKAAN}

Barclay, William. 1993. Pemahaman Alkitab Setiap Hari: Surat-Surat Yohanes dan Surat Yudas. Jakarta: BPK Gunung Mulia, 1993.

Berkhof, Louis. 2001. Teologi Sistematika Volume 3 Doktrin Kristus. Surabaya: Lembaga Reformed Injili Indonesia. Cetakan ketiga.

Brill, J.W. Dasar yang Teguh. Bandung: Penerbit Kalam Hidup. Cetakan Keenam.

Manton, M.E. 1995. Kamus Istilah Teologi: Inggris-Indonesia. Yayasan Gandum Mas.

Ryrie, Charles C. 1991. Teologi Dasar 1. Yogyakarta: Yayasan ANDI, Cetakan pertama.

Saligo Joseph V. 1997. Tanya Jawab Tentang Doktrin Kristen. Bandung: Yayasan: Kalam Hidup. Cetakan pertama.

Soedarmo, R. 1986. Kamus Istilah Theologia. Jakarta: BPK Gunung Mulia. Thiessen, Henry Clarence. 1992. Teologi Sistematika. Malang: Penerbit Gandum Mas. Cetakan pertama.

Verkuyl. J. 1966. Fragmenta A pologetika. Jakarta: Badan Penerbit Kristen.

${ }^{12}$ Henry C. Thiessen, Teologi Sistematika (Malang: Penerbit Gandum Mas, 1992). 
Diakui atau tidak, seorang hamba Tuhan (full time) yang telah belajar untuk memberdayakan jemaatnya ikut bertanggung jawab terhadap keseluruhan pelayanan gereja akan memiliki akses yang lebih luas untuk menjangkau masyarakatnya. Hal ini dikarenakan jemaat dengan berbagai latar belakang, profesi, dan status sosial akan menjadi "perpanjangan tangan" gereja untuk melayani dan memberkati masyarakat di sekitar tempatnya berada. Seorang hamba Tuhan, karena berbagai kesibukan tugas dan pelayanan gerejawi, seringkali mengalami keterbatasan dalam ruang lingkup pergaulannya. Waktu, tenaga, dan pikirannya diarahkan sepenuhnya kepada pelayanan-pelayanan dalam gereja sehingga hanya tersisa sedikit saja untuk ia dapat meluaskan pergaulannya dan memberikan sumbangsih kepada masyarakatnya. Sedikit banyak, keterbatasan ruang lingkup pergaulannya ini dapat diperluas oleh jemaatnya. Jemaat yang mungkin adalah pejabat pemerintah, usahawan, guru, dokter, pegawai, dsb. akan menjadi perpanjangan tangan gereja yang sangat efektif, yang tidak mungkin dapat dijangkau seluruhnya hanya oleh gembala dan teman-teman sekerjanya. Dengan demikian gereja akan mengalami perluasan wilayah dan jangkauan dalam pelayanannya, dan bukankah hal ini yang sesungguhnya dirindukan oleh pemimpin gereja manapun?

\section{Sisi Keuntungan yang Lain}

Berdasarkan pengamatan dan pengalaman penulis ada sisi keuntungan yang lain yang akan diperoleh dari gereja yang memberdayakan jemaatnya untuk terlibat secara aktif dalam keseluruhan pelayanan gerejawi itu sendiri, yaitu pertumbuhan iman/rohani yang lebih cepat bagi jemaat. Seringkali ditemukan dan didengar banyaknya keluhan dari para hamba Tuhan tentang jemaatnya yang menjadi 'kritikus' dan 'hakim' dalam gereja. Penulis melihat bahwa akar persoalan ini terletak pada ketiadaan 'rasa memiliki' (sense of belonging) jemaat terhadap kehidupan dan pelayanan gerejanya sendiri. Bilamana jemaat diberi kepercayaan dan kesempatan yang lebih luas untuk berperan serta dalam gerak dan aktifitas gereja maka rasa memiliki akan bertumbuh yang pada gilirannya akan meminimalkan pikiran, tindakan, dan ucapan (obrolan) negatif. Jemaat yang aktif akan berjuang untuk mengatasi pergumulan-pergumulan gerejanya ketimbang menjadi 'kritikus' oleh karena adanya kesadaran bahwa ia pun berada di dalam lingkup pergumulan-pergumulan itu sendiri. Jemaat yang diberdayakan untuk aktif akan mengetahui apa yang harus dilakukannya untuk gerejanya dan bagaimana gerejanya dapat memberi kontribusi yang lebih 
Ada beberapa keburukan metode ini: sering membosankan, tidak memperhatikan kebutuhan-kebutuhan murid, memadamkan inisiatif murid dan melatih.para murid untuk bergantung pada orang lain untuk pendapat mereka.

\section{Metode Demonstrasi}

Dengan metode ini guru dapat langsung mempertunjukkan dengan secara nyata apa yang dijelaskan secara abstrak. Agar berhasil, guru perlu mempersiapkan segala bahan yang dibutuhkan serta memberikan penjelasan yang sederhana sambil ia memberikan demonstrasinya. Contoh demonstrasi: bagaimana orang pada masa Perjanjian Lama berpakaian, cara murid-murid Yesus menjala ikan ataupun bagaimana orang pada masa dahulu menulis pada gulungan Kitab Suci.

\section{Metode Audio-visual}

Guru mempersiapkan kaset, film ataupun video yang akan diputarkan di kelas. Mutu kaset, film atau video harus tinggi karena metode ini meskipun menarik, tidak menguntungkan jika dipakai hanya untuk mengisi waktu. Sangat perlu dicoba dahulu di ruang kelas untuk memastikan bahwa apakah alat-alat teknis yang dibutuhkan untuk menjalankan alat audio-visual ini berjalan dengan baik.

\section{Matode mengajar yang berpusat pada murid}

\section{Metode Tanya Jawab}

Metode ini seperti metode bercerita termasuk metode mengajar yang paling lama dipakai. Tanya jawab dipakai dalam sinagoge pada masa dahulu dan Yesus juga sering menggunakan metode ini dalam mengajar murid-murid-Nya. Perjanjian Baru mencatat lebih dari 100 pertanyaan yang Yesus ajukan kepada orang yang diajar-Nya. Metode ini melibatkan guru dan para murid dalam proses belajar mengajar karena pertanyaan dapat diajukan oleh guru kepada murid, murid kepada guru, dan murid kepada murid. Sebaiknya bila guru merencanakan dan menulis lebih dahulu pertanyaan-pertanyaan yang akan diajukan kepada murid. Harus dihindari pertayaan yang dapat dijawab dengan "ya", "tidak" atau jawaban lain yang tidak menuntut pikiran.

Pertanyaan guru kepada murid mempunyai beberapa fungsi.

- Untuk membimbing pikiran - sebaiknya dipakai kata-kata tanya seperti

"Mengapa" dan "Bagaimana". 
Korintus 15:17-20, "Dan jika Kristus tidak dibangkitkan, maka sia-sialah kepercayaan kamu dan kamu masih hidup dalam dosamu. Demikianlah binasa juga orang-orang yang mati dalam Kristus. Jika kita hanya menaruh pengharapan pada Kristus, maka kita adalah orang-orang yang paling malang dari segala manusia. Tetapi yang benar ialah bahwa Kristus telah dibangkitkan dari antara orang mati, sebagai yang sulung dari orang-orang yang telah meninggal."

Berikut ini akan dikemukakan bukti-bukti bahwa Kristus sungguh telah bangkit dari antara orang mati.

Pertama, Penampakan-Nya setelah kebangkitan. Jumlah dan bermacam-macam orang dalam berbagai situasi yang melihat Tuhan setelah kebangkitan-Nya memberikan bukti yang menakjubkan terhadap kenyataan bahwa la sudah bangkit dari antara orang mati. Adapun uruturutan penampakan-penampakan antara kebangkitan Kristus dan kenaikan-Nya ke sorga adalah sebagai berikut: (1) kepada Maria Magdalena dan wanita-wanita lainnya (Matius 28:8-10; Markus 16: 910; Yohanes 20:11-18); (2) Kepada Petrus (Lukas 24:34; I Korintus 15:5); (3) kepada murid-murid-Nya di perjalanan ke Emaus menjelang petang (Markus 16:12; Lukas 24:13-32); (4) kepada murid-murid-Nya, kecuali Thomas di ruang atas (Lukas 24:36-43; Yohanes 20:19-25); (5) kepada murid-murid-Nya, termasuk Thomas pada Minggu malam berikutnya (Markus 16:14; Yohanes 20:26-29); (6) kepada tujuh orang murid di tepi Tasik Galilea (Yohanes $21: 1-24)$; (7) kepada para rasul dan lebih dari 500 saudara dan Yakobus, saudara tiri Tuhan Yesus (I Korintus 15:6-7); (8) kepada mereka yang menyaksikan kenaikan-Nya ke sorga (Matius 28:1820; Markus 16:19; Lukas 24:44-53; Kisah 1:3-12).

Kedua, Beberapa fakta yang menakjubkan yang membuktikan bahwa Kristus telah bangkit. (1) Kubur kosong. Murid-murid melihat bahwa kubur kosong. Para penjaga melaporkan kepada imam-imam kepala bahwa kubur kosong dan menerima suap untuk menutup mulut mengenai hal itu (Matius 28:11-15). Kubur itu kosong karena Kristus telah bangkit. (2) Turun-Nya Roh Kudus pada hari Pentakosta, seperti yang Kristus telah janjikan dalam Kisah Para Rasul 1:5 dan yang diperingati setiap tahun, merupakan kenyataan bahwa Kristus yang bangkit telah mengutus Roh itu (Kisah Para Rasul 2:33). Kedatangan Roh Kudus tersebut sudah cukup menjadi suatu penyebab atau alasan balıwa Kristus telah bangkit. (3) Hari Tuhan merupakan akibat dari kebangkitan Kristus. Semua orang Kristen yang pertama adalah orangorang Yahudi, yang terbiasa beribadah pada hari Sabat, namun secara tiba-tiba dan serentak mereka seragam mulai beribadah pada hari Minggu (Kisah Para Rasul 20:7). Karena mereka ingin memperingati 